\title{
Association of Borda's method and analytic hierarchy process (AHP) for the acquisition of helicopters by the Brazilian Navy
}

Eduardo Picanço Cruz ${ }^{1}$, Federal Fluminense University, Rio de Janeiro, Brazil

Carlos Navarro Fontanillas ${ }^{2}$, Federal University of Rio de Janeiro, Rio de Janeiro, Brazil

Karen Possoli ${ }^{3}$ Federal University of Rio de Janeiro, Rio de Janeiro, Brazil

Martius Vicente Rodriguez y Rodriguez ${ }^{4}$, Federal Fluminense University, Rio de Janeiro, Brazil

\section{RESUMO}

Objetivo - Combinar o Método da Análise Hierárquica (AHP) e o Método de Borda como sugestão para a tomada de decisão coletiva. Harmonizando a escala cardinal resultante do AHP com o Método de Borda, espera-se que a avaliação das alternativas de compra de helicópteros pela Marinha Brasileira maximize as opiniões individuais na construção da solução coletiva.

Metodologia - Qualitativa e quantitativa. Foram entrevistados os agentes envolvidos no projeto de aquisição de Helicópteros de Emprego Geral de Pequeno Porte da Marinha do Brasil - MB, dez pilotos e seis engenheiros militares da Diretoria de Aeronáutica da Marinha do Brasil no RJ. Os dados foram tratados combinando a escala cardinal resultante do AHP com a proposta do Método de Borda.

Resultados - Analisando as PMG's obtidas com o AHP, constata-se que a inconsistência dos julgamentos não afeta significativamente o resultado. Considera-se que ambos os processos são capazes de promover dentro da Marinha do Brasil um importante auxílio no processo de decisão em uma compra de aeronave para compor e melhorar sua frota na aviação naval. Da mesma forma, podem ser aplicados em situações similares de escolha entre alternativas excludentes.

Contribuições - A utilização de ferramentas híbridas (fruto da combinação de métodos) em uma análise multicritério auxilia as organizações a aproveitarem melhor os seus recursos disponíveis, principalmente em cenários de decisões complexas. Contribui com a possibilidade de levar os gestores a uma reflexão melhor sobre os limites de aceitação das decisões.

Palavras-chave - Decisões coletivas; Multicritério; Método de Borda; Método de Análise Hierárquica.

\section{ABSTRACT}

Purpose - A combination of the Analytic Hierarchy Process (AHP) and the Borda's Method as a suggestion for collective decision-making. By harmonizing the cardinal scale, resulting from the AHP, with the Borda's Method, it is expected that the evaluations of the alternatives for new helicopters maximize the individual opinions in the construction of a collective decision.

Design/methodology/approach - Qualitative and quantitative. The agents involved in the project of acquisition of helicopters for General Usage and Small Capacity for the Brazilian Navy were interviewed, ten pilots and six military engineers from Aeronautics Board of the Brazilian Navy in Rio de Janeiro. The data were treated by combining the cardinal scale resulting from the AHP with the method proposed by Borda.

Findings - Analyzing the MGP's obtained by AHP, it was possible to ascertain that judgment inconsistencies did not affect the result. It is considered that both methods are capable to promote a helpful decision aid inside the BN in the decision upon the purchase of an aircraft to substitute and enhance their naval aviation fleet. It is also considered that both methods can be applied in similar situation of decisions between mutually exclusive alternatives.

Originality/value - The usage of hybrid decision aids (created by the combination of methods) in a multicriteria analysis helps organizations make the best use of available resources, especially in complex decision scenarios. This study helps decision-makers to reflect about the process' tolerance limits.

Keywords - Collective decisions; Multicriteria; Borda's Method; Analytic Hierarchy Process.

1. Rua Mario Santos Braga, S/N - sala 703b - Campus do Valonguinho - Centro - Niterói - RJ - CEP 24020-140, epicanco@id.uff.br, http://orcid.org/0000-0003-4484-3256; 2. navarro.ufrj@ gmail.com, http:// orcid.org/ 0000-0002-5242-509X; 3. k.possoli@gmail.com, http:// orcid.org/0000-0001-9192-9197; 4. martiusrodriguez@id.uff.br, http:// orcid.org/0000-0001-82707488 .

CRUZ. E. P.; FONTANILLAS, C.N.; POSSOLI, K.; RODRIGUES Y RODRIGUES, M.V. Association of Borda's method and analytic hierarchy process (AHP) for the acquisition of helicopters by the Brazilian Navy. GEPROS. Gestão da Produção,

Operações e Sistemas, v. 15, n. 4, p. 23 - 47, 2020.

DOI: http://dx.doi.org/10.15675/gepros.v15i4.2432 


\section{INTRODUCTION}

The Brazilian Navy $(\mathrm{BN})$ vision statement includes being "permanently ready to act on the sea and interior waters, singularly or jointly" (MARINHA DO BRASIL, 2018). To ensure that vision, the Navy's aircraft fleet is being revitalized to attend their demand. Older machinery requires higher investments and longer periods for maintenance, which has an impact on their availability for missions.

According to the interview of Admiral Luiz Henrique Caroli, General Director of Materials from the BN, submitted to the Aerial \& Naval Defenses website and available at the BN's website, in 2016 the Navy received proposals for the acquisition of helicopters for General Usage and Small Capacity - Project UHP (Portuguese initials). UHP Project is a medium term goal of the BN and its purpose is to substitute all of the BN's fleet of aircrafts UH-12/13 (Squads HU-1, HU-3, HU-4 and HU-5) for new twin-engine aircrafts (PADILHA, 2018). These Fleet's principal tasks are Save and Rescue (SAR), Medical Evacuation (MEDEVAC), and Cargo and Troops Transportation. These tasks are all strongly connected to sovereignty and troops safety.

The purchase of a helicopter for this type of service, besides the high impact on the country's budget, is a complex decision which directly affects the performance of the Brazilian Navy on their main objectives. The Navy's Commander (Comandante da Marinha do Brasil) is the decision-maker, but he relies on technical reports, various evaluations and perspectives obtained along the decision process. The Aeronautics Board of the Brazilian Navy (DAerM - Portuguese initials) organizes a technical team, composed by pilots, military engineers, and others, to perform a thorough analysis of each aircraft model.

Traditionally, complex decisions are analyzed using more than one criterion in a combination that the literature refers to as 'Multi-Criteria Decision Making'. To mathematically threat the judgments made by decision makers, several methods have been developed through the last decade, such algorithms are denominated as 'multicriteria methodology for decision aiding' (ROY, 2013; YAGER, 2014.; GOMES, 2009; TREINTA et al, 2014; ALMEIDA; GOMES; GOMES, 2012; CRUZ; BARRETO; FONTANILLAS, 2014).

Worthy of special mention during the opening session of the National Meeting of Production Engineering (XXXVII ENEGEP), at Joinville-SC in 2017, Thomas Lorie Saaty 
developed the Method of Analytic Hierarchy Process (AHP), one of the most known and quoted methods throughout the world. Despite that, the application of this method to a situation with multiple decision makers is not a consensus in the literature, which is the gap this article aims to fill.

The question this article focus on is: What can be observed about the combination of these methods applied to a problem of great magnitude? In this regard, the purpose of this article is to combine the Borda's method and Analytic Hierarchy Process (AHP) as a possibility to a multiple decision-makers situation. As will be presented, the Borda's method was developed to improve the results of a collective decision. Thereby, harmonizing with the cardinal scale (LONGARAY et al., 2019) resulting from AHP, it is expected that the evaluations of the alternatives for new helicopters maximize the individual opinions in the construction of a collective decision.

A research at data base 'Web of Science', accessed through the website Periódicos CAPES, with the words 'multicritério' (multicriteria) and 'marinha' (navy), using the Boolean operator AND to fix the terms, did not identify scientific articles written between 1945 and 2019. The same response was obtained at SCOPUS and SciELO data bases. When using the terms 'multicritério' (multicriteria) and 'helicópteros' (helicopters), Web of Science and SCOPUS had no entries. SciELO data base had only one article identified. This particular article was about the identification of potential sites for Rainwater harvesting systems using a multicriteria spatial analysis in a Geographical Information System (GIS) environment at the East of Mexico State, aiming to use this sites for Aerial firefighting with a helicopter. This database search reinforces the originality of this article's subject.

\section{THEORETICAL FRAME OF REFERENCE}

The first multicriteria methodologies began with operational research techniques that were developed during the Second World War and had the United States Air Force as an important study Centre. There a research group under the name of Scientific Computation of Optimum Program - SCOP was organized with the purpose of solving the delicate problem of allocating limited resources aiming to achieve the targets set (RASKIN, 2016, LOESCH; HEIN, 2017). Many methods were created throughout the years. The Table 1 below highlights some of these methods, classified according to Wang et al (2009) categories: 
Table 1 - Multicriteria Methods

\begin{tabular}{|c|c|c|}
\hline Category & Method & Seminal Authors \\
\hline Classics & $\begin{array}{c}\text { Dominance Order } \\
\text { Maximin / Maximax } \\
\text { Lexicographic method } \\
\text { Borda } \\
\text { Condorcet }\end{array}$ & $\begin{array}{c}\text { Pareto (1896) } \\
\text { Wald (1945) } \\
\text { Chvatal and Chvatal (1983) } \\
\text { Borda (1781) } \\
\text { Condorcet (1788) }\end{array}$ \\
\hline $\begin{array}{l}\text { Single criteria approach } \\
\text { (American School) }\end{array}$ & $\begin{array}{l}\text { Smarts } \\
\text { AHP } \\
\text { Macbeth } \\
\text { UTA } \\
\text { Todim }\end{array}$ & $\begin{array}{c}\text { Edward and Barron (1994) } \\
\text { Saaty (2014) } \\
\text { Bana e Costa and Vansnick } \\
(1993) \\
\text { Jacquet-Lagrèze and Siskos } \\
(1982) \\
\text { Gomes (2009) }\end{array}$ \\
\hline $\begin{array}{c}\text { Outranking Method (French } \\
\text { School) }\end{array}$ & $\begin{array}{c}\text { Electre } \\
\text { Promethee }\end{array}$ & $\begin{array}{c}\text { Roy (2013) } \\
\text { Brans and Mareschal (1990) }\end{array}$ \\
\hline
\end{tabular}

Source: The authors.

Besides that, Roy and Bouyssou (1993) present four problems related to decision aid, classifying them according to their objectives:

1. Question description and cognition - which focuses in clarifying the decision by describing it in proper language (e.g.: brainstorming).

2. Selection Problem - which aims to select an alternative (e.g.: where to go during a vacation?).

3. Order Problem - of which the goal is to create a rank with the alternatives (e.g.: sports championships).

4. Classification Problem - which focuses on the screening process of the alternatives in predetermined categories, which may or may not be ranked (e.g.: classification of dogs according to their breed).

Hereinafter, both methods used in this article will be further detailed.

\subsection{Borda's Method}

Jean-Charles Borda's method, developed circa 1780, presented an alternative electoral voting system (MELLO, 2002). One of the issues with the traditional electoral system is that the most voted candidate (best option) can also be the candidate with the highest rate of rejection. Hypothetically, if at the back of the ballot paper there was an additional choice to be 
made: 'mark the worst desirable candidate', it would be possible that the candidate with more votes in favor would also be the one with more votes against (BORDA, 1781).

The system of 'one man, one vote' can be mathematically translated by the attribution of one point for the chosen alternative and zero for all the others - not being possible for each decision-maker individually to indicate a second option. According to our current election system, the second place is the candidate with the second highest number of votes, which does not necessarily indicate each voter's second choice. Besides, the electoral method is sensible to the withdrawal of a possible candidate. When one alternative is excluded, the votes that were originally assigned to it are relocated to other alternatives, what may lead to significant changes on the result (PRZEWORSKI; STOKES; MANIN, 1999).

To solve these issues, Borda proposed that instead of choosing one favorite alternative, the decision-maker created a ranking of the alternatives according to their preferences (CRUZ; BARRETO; FONTANILLAS, 2014). The rankings would form ordinal scales in accordance with the amount of available options, varying from 1 (lowest rating) to $n$ (highest rating), for $n$ alternatives.

To illustrate the method: in a system with three alternatives, the best option would receive three points, the second would receive two points, and the last would receive only one point. This way, in a collective decision, the "winning" alternative would be the one with the highest final rating, obtained by the summation of points attributed to the alternatives by each decision-maker.

One logical and important mathematical ascertainment is that the final result will be the same whether using the summation of points or the arithmetic average.

\subsection{Analytic Hierarchy Process - AHP}

Developed in the 1970's by Saaty, the Method of Analytic Hierarchy Process (AHP) has been extensively used as an aid for multicriteria decision-making. The popularity of this tool is due to the fact that this method reflects our intuitive and simple way of decision making, it utilizes simple mathematical resources and allows a broad application range (OLIVEIRA, 2017). According to Saaty (2014), the method structures the decision-making process, which makes it more agile and improves the approach of the problem. Saaty (2014) 
also emphasizes that AHP helps to quantify subjective judgements and transforms them in a set of priorities that can be used to support decisions.

Stecyk (2018) explains that the method has three stages: building a hierarchical structure, defining priorities, and checking the logical consistency. As ascertained by the method's creator (SAATY, 2014), there are no inviolable rules for creating a hierarchical structure, but he suggests a few options. Typically, at the higher level is the main goal; after that there are the criteria that must be fulfilled in order to achieve the goal; and at the lower level there are the alternatives that must be chosen or prioritized. The goal and the criteria may be subdivided as much as needed to ensure that all aspects are appropriately analyzed.

Based on these steps, a structure similar to the one depicted on Figure 1 is created.

Figure 1 - Method of Analytic Hierarchy Process.

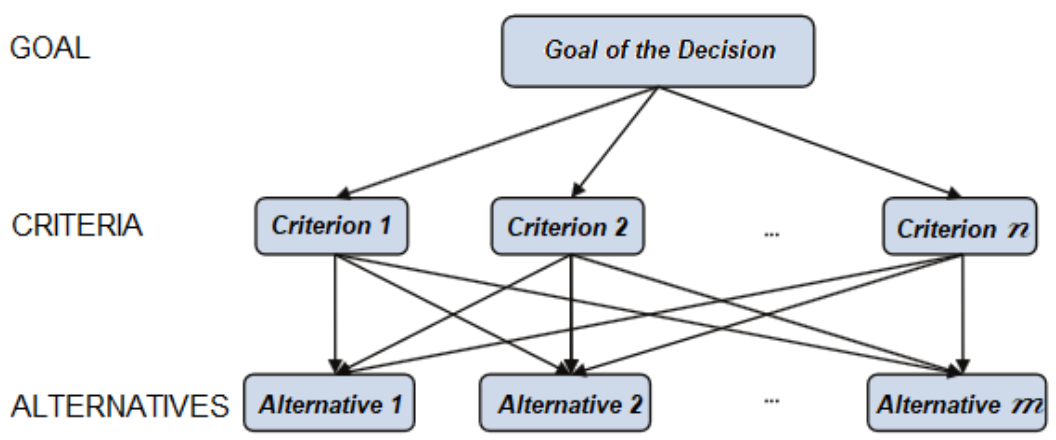

Source (Adapted from): (OLIVEIRA, 2017).

The 'defining priorities' stage includes the following steps:

a) Pairwise comparisons: a numerical weight is attributed to each criterion, according to their relative importance (Table 2). Alternatives are evaluated according to their relative importance, through pairwise comparison, using a Saaty Scale, that attributes absolute numerical values to quantitative and qualitative judgments (DANTAS, 2016). 
Table 2 - Saaty's scale with 9 fundamental weights for pairwise comparisons

\begin{tabular}{l|c}
\hline \multicolumn{1}{c|}{ Verbal Scale } & Numerical Scale \\
\hline Equal importance & 1 \\
\hline Moderate importance of one over another & 3 \\
\hline Essential importance & 5 \\
\hline Demonstrated importance & 7 \\
\hline Absolute importance & 9 \\
\hline Intermediate values between the two adjacent judgments & $2,4,6,8$ \\
\hline
\end{tabular}

Source: (STECYK, 2018).

Considering that, Stecyk (2018) argues that the amount of judgments necessary to create a square pairing matrix $\mathrm{A}$ is $n(n-1) / 2$, where $n$ is the number of elements in each matrix. The elements of matrix A are defined by the following conditions:

$$
A=\left[\begin{array}{cccc}
1 & a_{12} & \cdots & a_{1 n} \\
1 / a_{21} & 1 & \cdots & a_{2 n} \\
\vdots & \vdots & \cdots & \vdots \\
1 / a_{n 1} & 1 / a_{n 2} & \cdots & 1
\end{array}\right], \text { where: } \begin{aligned}
& a_{i j}>0 \Rightarrow \text { positive } \\
& a_{i j}=1 \therefore a_{j i}=1 \\
& a_{i j}=1 / a_{j i} \Rightarrow \text { reversible } \\
& a_{i k}=a_{i j} \cdot a_{j k} \Rightarrow \text { consistency }
\end{aligned}
$$

b) Calculation of normalized square pairing matrix.

c) Calculation of mean local priorities (MLPs), that are obtained for each item of judgment or normalized matrix. MLPs are the mean of each column of a normalized matrix (TRAMARICO, 2016).

d) Calculation of global priorities, to create a vector of the mean global priorities (MGPs) that summarizes the priority associated with each alternative regarding the main goal (STECYK, 2018).

Tramarico (2016) suggests that even when pairwise comparisons are based on experience and technical knowledge, inconsistencies may occur - especially when working with a higher number of judgements. So, the final stage of the Analytic Hierarchy Process is to verify the level of inconsistencies in the pairwise comparison matrix.

Stecyk (2018) calculates the consistency ratio by C.R. = C.I./R.I., where R.I. is a random consistency index generated for a square matrix of size $n$, with non-negative elements and automatically generated. The consistency index C.I. is given by the equation C.I. $=\left(\lambda_{\text {máx }}\right.$ 
$-n) /(n-1)$, where $\lambda_{\text {max }}$ is the largest own size of the matrix. Saaty (2014) considers that consistency ratios of less than 0.1 are acceptable, once comparison matrices are created by human judgments, which are intrinsically inconsistent.

\section{METHODOLOGICAL PROCEDURES}

The data that are the corpus of this article are of mixed nature: qualitative and quantitative (COOPER; SCHINDLER, 2016). This research's universe is composed by agents involved in the project of acquisition of helicopters for General Usage and Small Capacity for the Brazilian Navy, with the purpose of buying small-sized twin-engine military aircrafts to substitute the UH-12 and UH-13. Project UHP, as called by the BN, will impact squads HU-1, based at São Pedro da Aldeia - RJ, HU-3 based at Belém - PA, HU-4 based at Ladário - MS and HU-5 based at Rio Grande - RS. A non-probabilistic sample was utilized, and it was selected because of its accessibility (FREITAG, 2018) during interviews with agents involved in the UHP Project. The sample consists in ten pilots and six military engineers from Aeronautics Board of the Brazilian Navy (DAerM).

The main goal of the interviews with the military staff was to collect data about their preferences regarding the question: which is the best helicopter model to meet the naval aviation demands of the Brazilian Navy. Interviews took place at military base of the BN in Rio de Janeiro, during approximately 30 minutes each, and consisted in creating pairwise comparison matrices, as described in item 2.2. After that, the interviewed officials analyzed the importance of each criterion for this particular project, being the main goal to maximize the positive effects of this purchase for the Brazilian Navy.

Once all the data was collected, the researchers submitted the responses to the mathematical treatment proposed by Saaty (2014) using, for such, the IPÊ 1.0 software. That made possible to generate the individual scales of preferences. Means and standards deviation were calculated to be applied to Borda's Method in order to achieve a collective decision.

Case studies, like the one here presented, are particularly interesting for explanatory studies and for building theories (EISENHARDT, 1989). Yin (2013) established robust procedures for the development of case studies, which have been followed by the researchers regarding the format of the interviews and data evaluation. 


\section{PROPOSAL FOR COMBINING BORDA'S METHOD WITH AHP}

This paper proposes the combined usage of two methods to achieve a more adequate solution to the problem. Nevertheless, when the decision-maker compares alternatives through a direct judgment (graduation with a numerical value), some complicating factors must be considered. Dilemmas related with this kind of decision were described by Cruz, Barreto and Fontanillas (2014): (a) the brand's dilemma: when the decision-maker has a strong difficulty to address a low rating score to alternatives that he, beforehand, considers a good option or vice-versa. That happens when a decision-maker has a preliminary concept that an alternative is good or bad. Lately, neuroscience explains this type of behavior due to variations of dopamine levels (molecule that allows neurons to communicate), highlighting that human beings have the tendency to repeat decisions that lead to good previous experiences and to repel those that had been bad (LEHER, 2010); (b) the teacher's dilemma: when the decision-maker, analyzing too many alternatives in a row, has a difficulty to keep a pattern of evaluation. Frequently, the exhaustion caused by complex decisions leads to a relaxation of the original pattern.

Authors also point out that, when using Borda's Method, the decision-maker is subjected to a mathematical imprecision that becomes more perceptible when there is a greater discrepancy between the level of preference for each alternative. That occurs because when utilizing an ordinal scale to perform the judgment, all alternatives remain equally spaced in the order of preference created. In other words, when Borda suggested the use of a rating system that is formed with integral and sequential numbers $(1,2,3, \ldots, n)$, he made the decision-maker consider that the alternative that received two points has double the preference of the one that received one point.

This example demonstrates the imprecision in the hierarchy of preferences made by the decision-maker when using an ordinal scale as proposed by the Borda's Method. That makes it necessary to implement a cardinal scale (LONGARAY et al., 2019). However, to let the decision-maker freely rate the alternatives in a cardinal scale would incur in a reversion for the original voting system (one man, one vote), since the decision-maker can give points only for his favorite option, and leave the other options with no points, deliberately. Besides, even if well intended and in a fair judgment, a decision-maker would be susceptible to the dilemmas presented by Cruz, Barreto and Fontanillas (2014). The current paper proposes, in 
order to avoid these issues, the usage of the cardinal scale from Saaty's Method of Analytic Hierarchy Process (AHP), which then will be used to create the rating for using Borda's Method.

As a result, it is expected that the Borda's scale crafted as proposed, will more accurately represent the order of preference of the decision makers and that the pairwise comparison will lessen the effect of the decision-makers' dilemmas. The main goal is to enhance the sensibility of the result obtained by the Borda's Method by using an indirect ordinal scale based on judgments made on a cardinal scale (AHP).

\section{CASE PRESENTATION AND FINDINGS}

The UHP Project aims to purchase light military aircrafts to substitute the helicopters UH-12 and UH-13, that compose the naval aviation fleet of squads HU-1 at São Pedro da Aldeia - RJ , HU-3 at Belém - PA, HU-4 at Ladário - MS, and HU-5 at Rio Grande - RS. The replacement of this aircrafts will increase the availability of the squads, and their operational capacity. For this Project, it is important that the helicopter is versatile and fulfills all the requirements prescribed by the navy.

\subsection{Criteria}

For selecting a helicopter for military usage defined at UHP Project, the following criteria are decisive:

a) Cruise Speed: the highest velocity developed by the aircraft without affecting normal flight levels, which means no increase in fuel consumption, trepidation, or noise level.

b) Maximum Endurance: Since many missions are performed above the ocean, with no possibility for refueling, the maximum endurance will be evaluated.

c) External Load Capacity: Load Capacity through a hook connection. Hook is an attachment placed at the bottom of the aircraft through which it is possible to carry loads. This function allows transport of supplies to isolated regions where access by ship is restricted.

d) SAR/MEDEVAC Configuration: Save and Rescue configuration is used to locate people, aircrafts or vessels that disappear along the Brazilian coast. Medical GEPROS. Gestão da Produção, Operações e Sistemas, v.15 n. 4, p. 23-47, 2020. 
evacuation consists in transferring hurt/sick people from vessels along the coast to a medical care facility. For this type of missions, the helicopter must have a seat configuration that allows, at least, one stretcher plus two seats (one for a healthcare professional and other for the flight mechanic.

e) Number of Crewmen: These aircrafts will also be used for passenger's transportation. In this criterion, only the number of crewmen besides the fixed crew will be considered (two pilots and one flight mechanic).

Due to national security restrictions, this article will stick to public domain criteria. Price and weaponry configuration will not be evaluated.

\subsection{Alternatives}

The alternatives for the AHP are the aircrafts presented to the Brazilian Navy, according to interview of Fleet Admiral Luiz Henrique Caroli, Navy's Materials General Director (PADILHA, 2018). These helicopters are the following:

a) AW 109: produced by AgustaWestland, is a small-sized general usage helicopter, with cruise speed of $285 \mathrm{~km} / \mathrm{h}$ and endurance of $01 \mathrm{~h} 30 \mathrm{~min}$. For missions of SAR/MEDEVAC, it is capable to transport one stretcher and three extras seats. Its HOOK equipment can handle load transfers up to $1,000 \mathrm{~kg}$. For passenger's transport, this aircraft can carry five passengers.

Figure 2 - AW 109

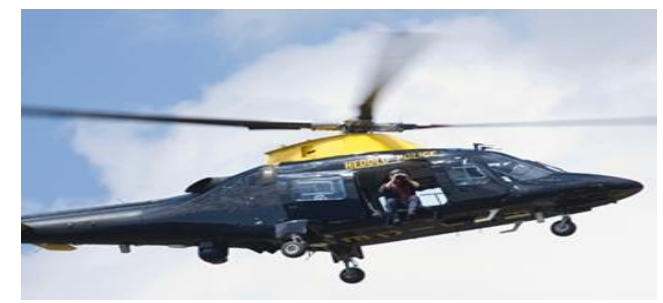

Source: Manufacturer website. Available at http://www.leonardocompany.com/-/aw109-power-2.

b) BELL 429: Model offered by BELL HELICOPTER Manufacturer, with flight endurance of $3 \mathrm{~h}$ and cruise speed of $272 \mathrm{~km} / \mathrm{h}$. For SAR/MEDEVAC missions, can carry one stretcher and two extra seats. Its HOOK equipment can handle loads up to $1,200 \mathrm{~kg}$. For crew transport, this helicopter has 5 seats available. 
Figure 3 - BELL 429

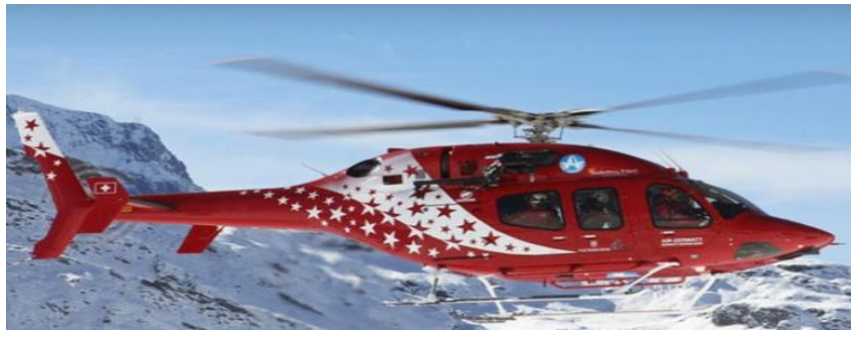

Source: Manufacturer website. Available at http://www.bellflight.com/commercial/bell-429.

c) EC 645: produced by EUROCOPTER in a partnership with HELIBRAS, it has a cruise speed of $252 \mathrm{~km} / \mathrm{h}$ and endurance of $3 \mathrm{~h} 30 \mathrm{~min}$. It is capable of transporting 8 passengers and its $\mathrm{HOOK}$ equipment can sustain loads up to $1,500 \mathrm{~kg}$. For the SAR/MEDEVAC Configuration, this aircraft can carry one stretcher plus six passengers, or two stretchers and 3 passengers.

Figure 4 - EC645

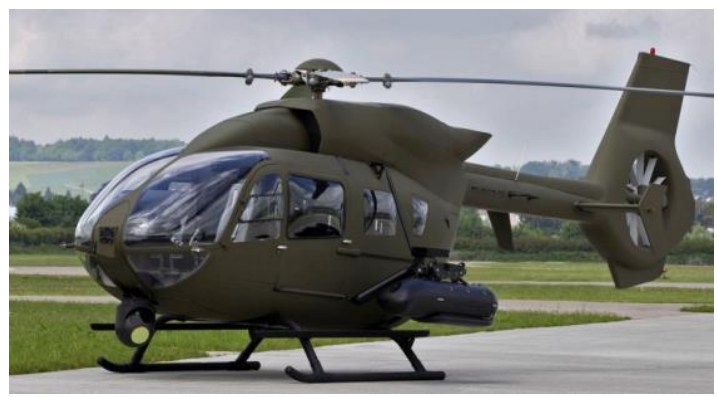

$\begin{array}{llll}\text { Source: } & \text { Manufacturer } & \text { website. } & \text { Available }\end{array}$ http://www.helibras.com.br/website/po/ref/H145M_35.html.

\subsection{Findings and Discussions}

To judge the alternatives according to the stablished criteria, sixteen military officials of the Brazilian Navy were selected, in a group composed by pilots and engineers. These military men were divided in two groups according to their duty. The first group, called the technical team, is composed by six engineers involved in the UHP Project. The second group is formed by ten military pilots, all of which, besides knowing the characteristics of each aircraft, will also base their judgment on their own personal experience as pilots for the Aeronautic Naval Department of the BN. 
Once the judgement of the alternatives was made by the respondents, the data was input to the software IPE 1.0, which performs the calculations of AHP's Method (SAATY, 2014). The software normalizes the matrix, calculates MLP's, GMP's and C.I.'s, and presents the results for the evaluation of the decision-maker. The results were analyzed first for each individual group (technical team/pilots), and then merged to point a final decision.

Due to restricted access, it was not possible to schedule a second meeting to consolidate the judgements first made in an effort to diminish the inconsistency levels found. Therefore, in this article, results with an inconsistency rate of over $10 \%$ will be analyzed. That can be considered as a limitation of this work, but it does not preclude the findings of this article. The MLP's of the responder's judgements are presented below, and the inconsistencies ratios are highlighted.

Table 3 - MLP of alternative's judgement - Technical Team

\begin{tabular}{|c|c|c|c|c|c|c|c|c|c|}
\hline & & $\begin{array}{c}\text { TEC } \\
1 \\
\end{array}$ & $\begin{array}{c}\text { TEC } \\
2 \\
\end{array}$ & $\begin{array}{c}\text { TEC } \\
3 \\
\end{array}$ & $\begin{array}{c}\text { TEC } \\
4 \\
\end{array}$ & $\begin{array}{c}\text { TEC } \\
5 \\
\end{array}$ & $\begin{array}{c}\text { TEC } \\
6 \\
\end{array}$ & MEAN & $\mathrm{SD}$ \\
\hline \multirow{4}{*}{ Endurance } & $\mathrm{AW}$ & 5.7 & 5.7 & 5.7 & 6.7 & 5.7 & 6.5 & 6.0 & 0.4 \\
\hline & BELL & 29.5 & 29.5 & 29.5 & 46.7 & 29.5 & 23.4 & 31.4 & 7.2 \\
\hline & $\mathrm{EC}$ & 64.8 & 64.8 & 64.8 & 46.7 & 64.8 & 70.1 & 62.7 & 7.4 \\
\hline & IC & 7 & 7 & 7 & $\mathbf{0}$ & 7 & 40.6 & 11.4 & 13.3 \\
\hline \multirow{4}{*}{ Cruise Speed } & $\mathrm{AW}$ & 60.7 & 65.8 & 57.4 & 63.3 & 63.3 & 9 & 53.3 & 20.0 \\
\hline & BELL & 30.3 & 25.3 & 28.6 & 26 & 26 & 60.7 & 32.8 & 12.6 \\
\hline & $\mathrm{EC}$ & 9 & 8.9 & 14 & 10.7 & 10.7 & 30.3 & 13.9 & 7.5 \\
\hline & IC & 11.9 & 26.5 & 11.8 & 3.3 & 3.3 & 11.9 & 11.45 & 7.7 \\
\hline \multirow{4}{*}{ Load Transport } & $\mathrm{AW}$ & 8.8 & 7.1 & 8.8 & 10.7 & 6 & 10.6 & 8.7 & 1.7 \\
\hline & BELL & 24.3 & 18 & 24.3 & 26 & 19 & 26 & 22.9 & 3.2 \\
\hline & $\mathrm{EC}$ & 66.9 & 74.9 & 66.9 & 63.3 & 75 & 63.4 & 68.4 & 4.9 \\
\hline & IC & 0.6 & 2.5 & 0.6 & 3.3 & 18.9 & 3.3 & 4.9 & 6.4 \\
\hline \multirow{4}{*}{$\begin{array}{c}\text { SAR/MEDEVAC } \\
\text { Configuration }\end{array}$} & $\mathrm{AW}$ & 5.9 & 8.8 & 20 & 8.3 & 8.8 & 10.2 & 10.3 & 4.5 \\
\hline & BELL & 17.4 & 24.3 & 20 & 19.3 & 24.3 & 21.1 & 21.1 & 2.5 \\
\hline & $\mathrm{EC}$ & 76.7 & 66.9 & 60 & 72.4 & 66.9 & 68.7 & 68.6 & 5.2 \\
\hline & IC & 27.4 & 0.6 & 0 & 5.7 & 0.6 & 12 & 7.7 & 9.8 \\
\hline \multirow{4}{*}{ Crewmen } & AW & 15.8 & 14.3 & 20 & 14.3 & 11.1 & 14.3 & 15.0 & 2.7 \\
\hline & BELL & 18.7 & 14.3 & 20 & 14.3 & 11.1 & 14.3 & 15.5 & 3.0 \\
\hline & $\mathrm{EC}$ & 65.5 & 71.4 & 60 & 71.4 & 77.8 & 71.4 & 69.6 & 5.6 \\
\hline & IC & 2.5 & 0 & 0 & 0 & 0 & 0 & 0.4 & 0.9 \\
\hline
\end{tabular}

Source: The authors. 
Table 4 - MLP of criteria's judgement - Technical Team

\begin{tabular}{c|c|c|c|c|c|c|c|c|c}
\cline { 3 - 10 } \multicolumn{2}{c|}{} & TEC & TEC & TEC & TEC & TEC & TEC & & \\
\hline \multirow{4}{*}{$\begin{array}{c}\text { MAIN } \\
\text { GOAL }\end{array}$} & Endurance & 22.9 & 45.1 & 4.3 & 32.3 & 45.1 & 48.2 & 33.0 & 15.5 \\
\cline { 2 - 10 } & Cruise Speed & 4.2 & 18.1 & 8.7 & 4.7 & 18.1 & 26.4 & 13.4 & 8.1 \\
\cline { 2 - 10 } & Load Transport & 19 & 16.9 & 23.6 & 13.9 & 16.9 & 13.4 & 17.3 & 3.4 \\
\cline { 2 - 10 } & SAR/MEDEVAC Config. & 31 & 2.8 & 15.2 & 36.2 & 2.8 & 3.4 & 15.2 & 13.8 \\
\cline { 2 - 10 } & Crewmen & 22.9 & 17.1 & 48.2 & 12.9 & 17.1 & 8.6 & 21.1 & 12.9 \\
\hline & IC & $\mathbf{3}$ & $\mathbf{6 . 2}$ & $\mathbf{7 . 3}$ & $\mathbf{6 . 4}$ & $\mathbf{6 2}$ & $\mathbf{2 7 . 5}$ & $\mathbf{1 8 . 7}$ & $\mathbf{2 1 . 0}$ \\
\hline
\end{tabular}

Source: The authors.

Table 5 - MGP - Technical Team

\begin{tabular}{c|c|c|c|c|c|c|c|c|c}
\cline { 3 - 10 } \multicolumn{2}{c}{} & TEC & TEC & TEC & TEC & TEC & TEC & & \\
\hline \multirow{3}{*}{ MGP } & AW & 11 & 18.37 & 20 & 11.46 & 17.17 & 8.51 & 14.4 & 4.3 \\
\cline { 2 - 11 } & BELL & 22.3 & 24.03 & 22.17 & 28.74 & 23.79 & 32.7 & 25.6 & 3.8 \\
\cline { 2 - 10 } & EC & 66.7 & 57.6 & 57.83 & 59.8 & 59.04 & 58.79 & 60.0 & 3.1 \\
\hline
\end{tabular}

Source: The authors.

At the endurance criteria, although the inconsistency level of Technician 6 is the highest for Table 3, a pattern of preference for Eurocopter's alternative by the technician in this aspect is perceptible.

Analyzing the judgments of this criteria (Table 3), it is possible to infer that, if using the traditional election system (BORDA, 1781), the engineers 1, 2, 3, 5 and 6 would have voted for Eurocopter's aircarft - because it had the highest score. Technician 4 seems to find Bell's helicopter as good as Eurocopter's in this criterion. If he had voted for Eurocopter, it would have $100 \%$ of the votes, and the others would have $0 \%$. If he had voted for Bell, the result would be $83 \%$ in favor of Eurocopter (5 votes out of 6 ) and $17 \%$ for Bell. Whereas MLP of endurance criterion indicates a mean preference of $6 \%$ for AW109 Helicopter, 31.4\% for Bell and $62.7 \%$ for Eurocopter. This difference underlines that the traditional election system method points out a solution but is not precise regarding order or categorization (ROY; BOUYSSOU, 1993). The cardinal scale (LONGARAY et al., 2019) generated through AHP (SAATY, 2014) offers a more accurate solution, despite the inconsistencies - which would probably exist, even in traditional election.

About the Cruise Speed criterion, technicians were more inconsistent in the answers. Although the answers of engineer 2 are more inconsistent than those of engineer 6, when 
compared with mean values, technician's 2 values are closer to the global result. In this criterion AW109 aircraft is the preferable one, and EC645 had the lowest score. Analogously to the previous analysis, all but technician 6 would have voted for AW109, and that would generate a preference rate of $83 \%$ for AW if using a traditional election method (BORDA, 1781). The Saaty's scale (2014) once more demonstrates to be more adequate to solve problems of order and classification (ROY; BOUYSSOU, 1993). The Standard deviation of this criterion is the highest calculated, and the one that would have the highest impact in the decision of which aircraft to choose.

Criteria of Load Transport, SAR/MEDEVAC Configuration, and Crewmen present a high level of inconsistency in the answers of some member of the group but, as in the Endurance criterion, calculated values are consistent with the results obtained by the Mean. In these criteria, the Saaty's scale (2014) also seems more adequate, because it addresses the problems of order and classification more precisely (ROY; BOUYSSOU, 1993).

According to the Means calculate in Table 4, the criterion of Cruise Speed has the lowest score, so that criterion would have the least impact on the final decision, and this diminishes the impact of this data on Table 5. However, inconsistency levels and high standards deviation make it important that this criterion is further analyzed.

There was a greater variation in the hierarchical order in which each criterion was analyzed (Table 4), when in comparison to the alternative's analysis, where most technicians had a consistent judgment, at least in an ordinal scale. Considering a decision process where the most voted alternative was the one elected as the critical one, it is identifiable that three technicians (2, 5 and 6) would consider endurance as the most important, technician 3 would choose Load Transport, technician 4 would choose SAR/MEDEVAC Configuration and technician 1 would consider Endurance as important as Crewmen capacity. Yet again the scale proposed by Saaty (2014) allows an enriched analysis, offering more information about the 'voters' decisions. Applying Borda's proposal to this situation, in other words, creating an ordinal scale with the votes of Table 4, the following would be observed: 
Table 6 - Comparison AHP X Borda

\begin{tabular}{c|c|c|c|c|c|c|c|c}
\cline { 2 - 9 } & TEC 1 & TEC 2 & TEC 3 & TEC 4 & TEC 5 & TEC 6 & SUM & AHP \\
\hline Endurance & 5 & 5 & 1 & 4 & 5 & 5 & 25 & 33.0 \\
\hline Cruise Speed & 1 & 4 & 2 & 1 & 4 & 4 & 16 & 13.4 \\
\hline Load Transport & 2 & 2 & 4 & 3 & 2 & 3 & 16 & 17.3 \\
\hline SAR/MEDEVAC Config. & 3 & 1 & 3 & 5 & 1 & 1 & 14 & 15.2 \\
\hline Crewmen & 4 & 3 & 5 & 2 & 3 & 2 & 19 & 21.1 \\
\hline
\end{tabular}

Source: The authors.

In this case, the original proposal made by Borda (1781) suggests the following order of preferences: the most relevant would be endurance ( 25 points), followed by the Crewmen Capacity (19 points), then a tie between Cruise Speed and Load Transport (16 points each) and the least relevant would be the SAR/MEDEVAC Configuration (14 points). As proposed by this article, by using AHP (SAATY, 2014) as a score for Borda's Method (Borda, 1781), the preference order would be: (a) endurance (the same as was obtained using Borda's Method); (b) Crewmen capacity (also consistent in both methods); (c) Load Transport, (d) SAR/MEDEVAC Configuration, and (e) Cruise Speed. These three criteria had a rank reversal compared to Borda's Method. Cruz, Barreto and Fontanillas (2014) had already pointed out that this could happen and emphasized that AHP is more appropriate for these types of qualitative judgements.

At last, the agglutination of results (MGP) corroborates the selection of Eurocopter's aircraft by the technical team. The only criterion where this aircraft did not obtain the best evaluation was Cruise Speed, but since this criterion was one of the least important according to their evaluation, it did not affect the global result.

Further analysis of the global result according to the technical team shows that the cardinal scales (LONGARAY et al., 2019) mean preferences indicates around $60 \%$ for Eurocopter, 25.6\% for Bell's helicopter and 14.4\% for AW. All technicians chose Eurocopter as their favorite one. This means that in a traditional voting system, questioned by Borda (1781), it would be elected with $100 \%$ of the votes. If, hypothetically, at the moment of purchase, the company had an internal problem and could not attend the demand, the purchase would be cancelled and another selection would have to be made, because there would be no 
data about a second best option. This information is only available due to the analysis proposed by Saaty (2014).

Table 7 - MLP of alternative's judgement - Pilots' Team

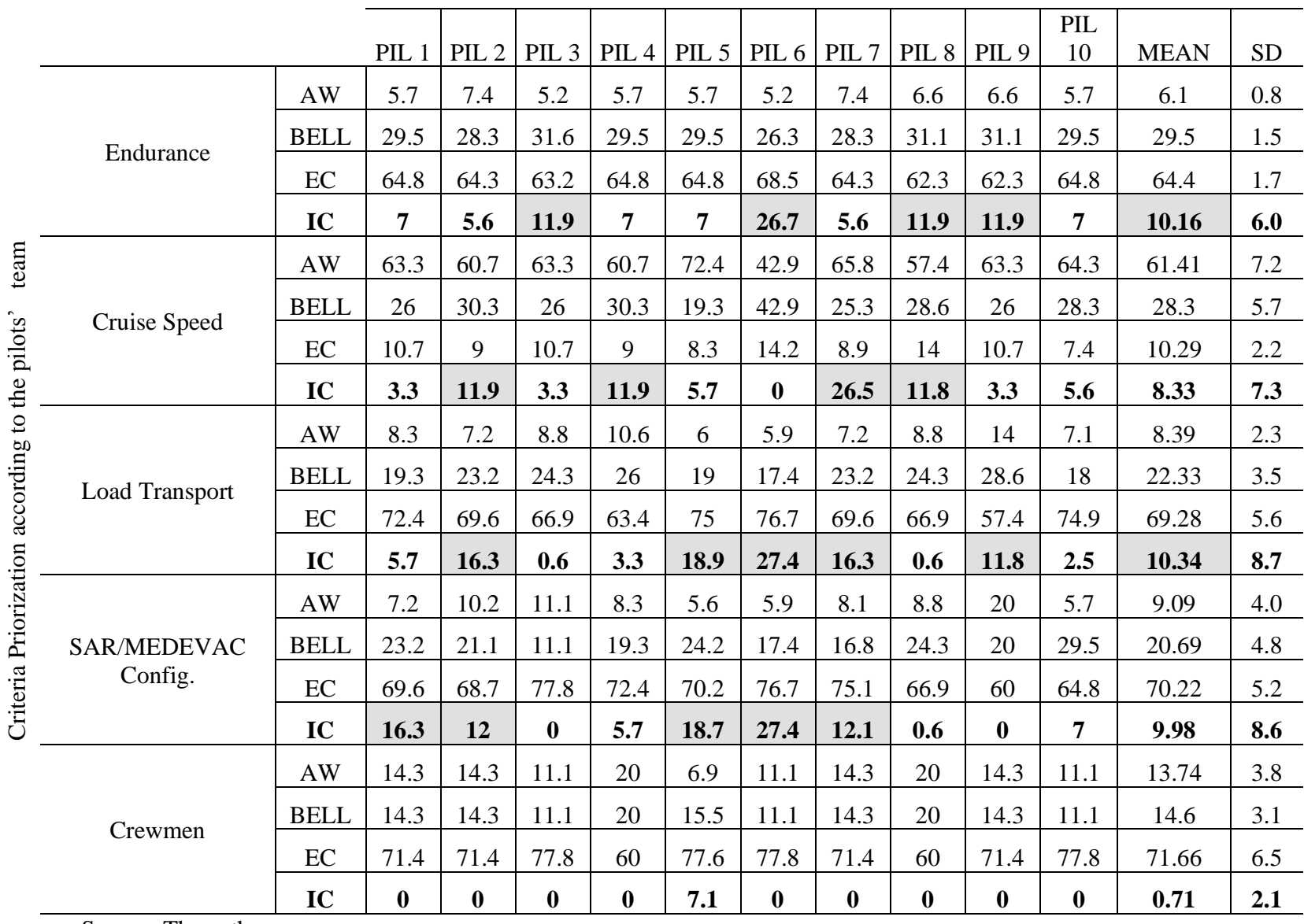

Source: The authors.

Table 8 - MLP of criteria's judgement - Pilots' Team

\begin{tabular}{|c|c|c|c|c|c|c|c|c|c|c|c|c|c|}
\hline & & $\begin{array}{c}\text { PIL } \\
1 \\
\end{array}$ & $\begin{array}{c}\text { PIL } \\
2 \\
\end{array}$ & $\begin{array}{c}\text { PIL } \\
3 \\
\end{array}$ & $\begin{array}{c}\text { PIL } \\
4 \\
\end{array}$ & $\begin{array}{c}\text { PIL } \\
5 \\
\end{array}$ & $\begin{array}{c}\text { PIL } \\
6 \\
\end{array}$ & $\begin{array}{c}\text { PIL } \\
7 \\
\end{array}$ & $\begin{array}{c}\text { PIL } \\
8\end{array}$ & $\begin{array}{c}\text { PIL } \\
9 \\
\end{array}$ & $\begin{array}{c}\text { PIL } \\
10 \\
\end{array}$ & MEAN & SD \\
\hline \multirow{6}{*}{$\begin{array}{l}\text { 通 } \\
\mho \\
z \\
z \\
\Sigma\end{array}$} & Endurance & 26.6 & 22.9 & 14.1 & 49.3 & 45.1 & 20.8 & 21.1 & 16.5 & 20.3 & 4.3 & 24.1 & 12.9 \\
\hline & Cruise Speed & 4 & 4.2 & 3.6 & 9.3 & 18.1 & 8.7 & 4.5 & 5.4 & 20.3 & 8.7 & 8.68 & 5.7 \\
\hline & Load Transport & 4 & 19 & 22.1 & 13.9 & 16.9 & 21.2 & 27.2 & 45.8 & 11.8 & 23.6 & & 11.7 \\
\hline & $\begin{array}{c}\text { SAR/MEDEVAC } \\
\text { Config. }\end{array}$ & 10.4 & 31 & 30.1 & 22.2 & 2.8 & 13.5 & 38 & 5.8 & 40.2 & 15.2 & 20.92 & 12.7 \\
\hline & Crewmen & 11.7 & 22.9 & 30.1 & 5.3 & 17.1 & 35.8 & 9.2 & 26.5 & 7.4 & 48.2 & 21.42 & 13.2 \\
\hline & IC & 2.7 & 3 & 10.6 & 7.5 & 62 & 49.5 & 13.4 & 15.1 & 8 & 7.3 & 17.91 & 19.5 \\
\hline
\end{tabular}

Source: The authors. 
Table 9 - MGP of Pilots' Team

\begin{tabular}{|c|c|c|c|c|c|c|c|c|c|c|c|c|c|}
\hline & & PIL 1 & PIL 2 & PIL 3 & PIL 4 & PIL 5 & PIL 6 & PIL 7 & PIL 8 & PIL 9 & PIL 10 & MEAN & SD \\
\hline \multirow{3}{*}{ MGP } & AW & 10.42 & 12.06 & 11.68 & 12.83 & 17.98 & 10.84 & 10.83 & 14.04 & 24.96 & 13.74 & 13.94 & 4.2 \\
\hline & BELL & 22.1 & 21.98 & 17.43 & 26.32 & 23.32 & 19.24 & 21.09 & 24.53 & 24.09 & 17.81 & 21.79 & 2.8 \\
\hline & EC & 67.48 & 65.96 & 70.89 & 60.85 & 58.7 & 69.92 & 68.08 & 61.43 & 50.95 & 68.45 & 64.27 & 5.9 \\
\hline
\end{tabular}

With rare exceptions, like the evaluation of Pilot 6 on Speed Cruise criterion, all values attributed to aircrafts are consistence with calculated means and present a lower standard deviation from the ones calculated for the Technical Team judgements. The preference for the helicopter EC645 was a constant, except for the Cruise Speed criterion. The inconsistency was more frequent, which means more pilots were inconsistent in their judgements, but the inconsistencies' means were numerically lower.

In accordance with the calculated means, the criterion of Cruise Speed would be the least important to the general evaluation of the aircraft, and in the individual judgements the score of this criterion never surpassed $21 \%$. This criterion, that is the only one where EC645 was the best evaluated, has a smaller weight in the outcome result.

The criteria judgment (Table 8) instead presents inconsistency levels equivalent to the ones presented in the technicians' judgments (Table 4). Standards deviation had similar levels in the judgement of pilots. It is noteworthy that Pilot 5, which had a higher level of inconsistency, was far from the patterns of means calculated for other pilots. For this member of the group Endurance has a greater importance than the calculated mean for the group, and Cruise Speed and Configuration has a rank reversal. It is possible that this happens because of the inconsistency level. However it is not unexpected that pilots with different backgrounds would prioritize criteria in accordance with the missions they are most familiar with, since the aircrafts of this project have a wide range of application.

The summarization of results from the Pilots' Team (Table 9) demonstrates a clear preference for the Eurocopter aircraft. As it happened with the Technical Team, the criterion in which EC645 was the least interesting choice was not decisive for the final result. Standard deviation between the alternatives from pilots' team was also low, despite the level of inconsistency of the analyzed answers.

In an analysis equivalent to the one performed for the Technical team judgement, an evaluation of the method of traditional electoral vote has shown to be inefficient, as suggested 
by Mello (2002). However, as described by Cruz, Barreto and Fontanillas (2014), when comparing answers with the original Borda's Method and the adaptation proposed by this article (as the example of Table 6), using AHP to create a cardinal scale to be implemented to Borda's allowed a better analysis of the answers - and could even be used in a possible audit of the decision process.

The aggregated results of calculations of local and global priorities for the whole group are as follow.

Table 10 - MLP - Global Result

\begin{tabular}{|c|c|c|c|c|}
\hline & & & MEAN & SD \\
\hline \multirow{20}{*}{ 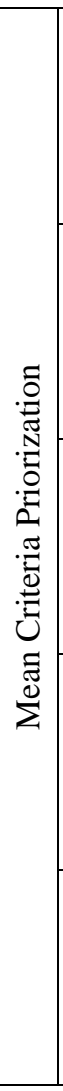 } & \multirow{4}{*}{ Endurance } & AW & 6.1 & 0.7 \\
\hline & & BELL & 30.2 & 4.7 \\
\hline & & $\mathrm{EC}$ & 63.8 & 4.8 \\
\hline & & $\mathrm{IC}$ & 10.6 & 9.5 \\
\hline & \multirow{4}{*}{ Speed Cruise } & AW & 58.4 & 14.1 \\
\hline & & BELL & 30.0 & 9.2 \\
\hline & & $\mathrm{EC}$ & 11.7 & 5.2 \\
\hline & & IC & 9.5 & 7.6 \\
\hline & \multirow{4}{*}{ Load Transport } & AW & 8.5 & 2.1 \\
\hline & & BELL & 22.6 & 3.4 \\
\hline & & $\mathrm{EC}$ & 69.0 & 5.4 \\
\hline & & IC & 8.3 & 8.4 \\
\hline & \multirow{4}{*}{$\begin{array}{l}\text { SAR/MEDEVAC } \\
\text { Config. }\end{array}$} & AW & 9.6 & 4.3 \\
\hline & & BELL & 20.8 & 4.1 \\
\hline & & $\mathrm{EC}$ & 69.6 & 5.3 \\
\hline & & IC & 9.1 & 9.1 \\
\hline & \multirow{4}{*}{ Crewmen } & AW & 14.2 & 3.5 \\
\hline & & BELL & 14.9 & 3.1 \\
\hline & & $\mathrm{EC}$ & 70.9 & 6.2 \\
\hline & & $\mathrm{IC}$ & 0.6 & 1.8 \\
\hline
\end{tabular}

Source: The authors.

Table 11 - MLP Criteria - Global Result

\begin{tabular}{|c|c|c|c|}
\hline & & MEAN & SD \\
\hline \multirow{4}{*}{  } & Endurance & 27.4 & 14.6 \\
\hline & Speed Cruise & 10.4 & 7.1 \\
\hline & Load Transport & 22.0 & 10.1 \\
\hline & SAR/MEDEVAC Config. & 18.8 & 13.4 \\
\hline
\end{tabular}


Source: The authors.

\begin{tabular}{c|c|c|c} 
& Crewmen & 21.3 & 13.1 \\
\cline { 2 - 3 } & IC & 18.2 & 20.1 \\
\hline
\end{tabular}

Source: The authors.

Table 12 - MGP - Global Result

\begin{tabular}{|c|c|c|c|}
\hline & & MEAN & SD \\
\hline \multirow{3}{*}{ 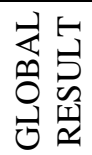 } & AW & 14.1 & 4.3 \\
\hline & BELL & 23.2 & 3.7 \\
\hline & $\mathrm{EC}$ & 62.7 & 5.5 \\
\hline
\end{tabular}

Global results represent the agglutination of the judgement of both teams, technicians and pilots, and maintains the previous verified preference. Eurocopter's EC645 was the chosen one with $62.7 \%$ of preference. Since the inconsistencies found throughout the judgements exceeded the $10 \%$ recommended by Saaty (2014) and due to the impossibility of refining the judgement matrices, a new calculation was made with only coherent judgements. The results obtained are depicted at Table 13.

Table 23 - MGP - Without Inconsistent Judgements

Source: The authors.

\begin{tabular}{|c|c|c|}
\hline \multirow{3}{*}{$\begin{array}{l}\text { 쥬 } \\
\stackrel{0}{0} 0 \\
\frac{0}{0}\end{array}$} & AW & 14.7 \\
\hline & BELL & 23.3 \\
\hline & $\mathrm{EC}$ & 62.0 \\
\hline
\end{tabular}

Deviations were under $1 \%$, validating the initial assumption that the inconsistence in the judgements would not invalidate the calculated result. In another approach, the numbers of Table 14 were calculated using the parity judgement to create a Borda's scale.

Table 34 - MPG calculate with Borda's Method

Source: The authors.

\begin{tabular}{|c|c|c|}
\hline \multirow{3}{*}{$\begin{array}{l}\bar{\pi} \\
\frac{0}{0} \\
\frac{0}{0}\end{array}$} & AW & 17 \\
\hline & BELL & 31 \\
\hline & $\mathrm{EC}$ & 48 \\
\hline
\end{tabular}


From an ordinal point of view, the hierarchy is maintained. But there is an interesting change in the cardinal positioning, which was intended to be demonstrated with the combination of methods proposed.

The EC645 that had a preference margin of 40\%, has a margin of only $17 \%$ over the Bellflight aircraft. With the usage of parity judgements with the Saaty's scale to construct the Borda's scale, rank reversal is prevented, but part of the sensibility is lost with a significant reduction of perceived preference between alternatives. However, this adjustment of the Borda's method ensures that dilemmas of direct valuation are avoided and guarantees a higher level of coherency when compared to a directly created scale of Borda (1781).

\section{CONCLUSION}

The purpose of this article was the question: "What can be observed about the combination of these methods applied to a problem of great magnitude?". As observed throughout this article's discussions, the usage of hybrid decision aids (created by the combination of methods) in a multicriteria analysis helps organizations make the best use of available resources, especially in complex decision scenarios. In this particular case, it is worth to highlight that the 'election' of best aircraft respected the individual hierarchies (cardinal scales) generated through parity judgements.

However, it is necessary to address the level of inconsistency on the decision-makers' judgements. Saaty (2014) suggests that inconsistency levels up to $10 \%$ can be considered acceptable. That is justifiable by the fact that all human judgements can be intrinsically inconsistent but, as shown by this article's example, complex problems can generate higher levels of inconsistency. A reflection on this result or a possible follow up study addressing this issue would be the proposal of a scientific study focusing on aggregated inconsistency levels. One possibility would be the usage of methods like MACBETH (LAMAS LEITE et $a l, 2017)$, because they do not generate inconsistent scales once the program blocks this type of judgement. But, when applied to an organization with a rigid hierarchy and with a strict line of command, like the Brazilian Navy, how could the analyst report to the Commander that he should redo his analysis, because he was inconsistent?

More refined tools and methods that demand a specific software can narrow down the calculus and allow applications that go beyond the 'best choice' decision. The downside is 
that it demands more time and trained labor than less sophisticated methods, such as Borda. The proposal of this article to create a preference scale of Borda through the parity judgements of AHP diminishes the effect of judgers' dilemma on the decisions.

What could be considered a limitation of this study is that such combination does not preserve the cardinal distribution of the alternatives, and so cannot be applied for resources allocation and probabilities judgements as proposed by Saaty (2014). Nonetheless, for cases of selection of a preferential alternative, it would be a more objective, quicker, and less complex solution.

Due to the application of this methodology, it was easy to identify, after a revision of the Theoretical Frame of Reference, that this combination makes the decision more precise for organizations as the Brazilian Navy, and for big companies that compete in the global market as well, where this kind of decision demands precision/sensibility. The possibility of a free judgement combined with a perfected way of voting also results in a better utilization of decision-makers judgements.

Analyzing the MGP's obtained by AHP, it was possible to ascertain that judgement inconsistencies did not affect the result, and differences of these results and the values calculated only with consistent judgements remained around 1\%, as it was intended. Even with this consideration, the preference rate for Eurocopter's aircraft is of $62 \%$, in an output that largely surpasses the remaining options. When using the method proposed for the combination with Borda's Method, Eurocopter had a preference rate of $48 \%$, and the preference ranking remains unaltered.

It is considered that both methods are capable to promote a helpful decision aid inside the $\mathrm{BN}$ in the decision upon the purchase of an aircraft to substitute and enhance their naval aviation fleet. It is also considered that both methods can be applied in similar situation of decisions between mutually exclusive alternatives.

As a practical application, it is expected that this study helps decision-makers who utilize multicriteria decision methods, based on consistency evaluations, to reflect about the process' tolerance limits. One possibility would be to analyze them according to Bounded rationality Theory (SIMON, 2013), which gave a Nobel Memorial Prize in Economic Sciences for the phycologist Hebert Simon. For future studies on this field, it is suggested the application of this combined method to other situations, and also the possibility of combining other methods with similar purposes. 


\section{References}

ALMEIDA, A. T.; GOMES, C. F. S.; GOMES, L. F. A. M. Tomada de Decisão GerencialEnfoque Multicritério. 2012.

BANA E COSTA, C. A.; VANSNICK, Jean-Claude. Sur la quantification des jugements de valeurs: l'approche Macbeth. Université de Paris Dauphine-Laboratoire d'analyse et modélisation de systèmes pour l'aide à la décision, 1993.

BORDA, J. C. Mémoire sur les élections au scrutin. 1781.

BRANS, J.P.; MARESCHAL, B. The PROMETHEE methods for MCDM; the PROMCALC, GAIA and BANKADVISER software. In: Readings in multiple criteria decision aid. Springer, Berlin, Heidelberg, 1990. p. 216-252.

CHVATAL, V.; CHVATAL, V. Linear programming. Macmillan, 1983.

CONDORCET, J. A. N. Essai sur la constitution et les fonctions des assemblées provinciales, 1788 .

COOPER, D. R.; SCHINDLER, P. S. Métodos de Pesquisa em Administração, $12^{a}$ Edição. McGraw Hill Brasil, 2016.

CRUZ, E. P.; BARRETO, C. R.; FOnTANillas, C. N. O Processo Decisório nas Organizações. Paraná: Intersaberes, 2014.

DANTAS, P. A. et al. Nível de evidenciação dos indicadores ambientais e sociais sob a perspectiva da análise hierárquica de processos (AHP) - um estudo exploratório nas empresas com melhor desempenho no índice de sustentabilidade empresarial (ise) em 2013. GEPROS. Gestão da Produção, Operações e Sistemas, v. 11, n. 1, p. 01 - 14, 2016.

EDWARDS, W.; BARRON, F. H. SMARTS and SMARTER: Improved simple methods for multi-attribute utility measurement. Organizational behavior and human decision processes, v. 60, n. 3, p. 306-325, 1994.

EISENHARDT, K. M. Building theories from case study research. Academy of management review, v. 14, n. 4, p. 532-550, 1989.

FREITAG, R. M. K. Amostras sociolinguísticas: probabilísticas ou por conveniência? Revista de Estudos da Linguagem, v. 26, n. 2, p. 667-686, 2018.

GOMES, L. F. A. M. et al. An application of the TODIM method to the multicriteria rental evaluation of residential properties. European Journal of Operational Research, v. 193, n. 1, p. 204-211, 2009. 
JACQUET-LAGREZE, E.; SISKOS, J. Assessing a set of additive utility functions for multicriteria decision-making, the UTA method. European journal of operational research, v. 10, n. 2 , p. $151-164,1982$.

LAMAS LEITE, J. G. et al. Using the MACBETH Method to improve the scenario analysis tool PESTEL in large civil construction projects. Dyna, v. 84, n. 203, p. 322-327, 2017.

LEHRER, J. O momento decisivo. Tradução Marcelo Schild. Rio de Janeiro: Best Business, 2010 .

LOESCH, C.; HEIN, N. Pesquisa operacional. Editora Saraiva, 2017.

LONGARAY, A. A. et al. Using MCDA-C to assess the organizational performance of industries operating at Brazilian maritime port terminals. Operations Research Perspectives, v. 6, p. 100109, 2019.

MARINHA DO BRASIL. Comando da Marinha. 2018. Disponível em: < https://www.marinha.mil.br/intendencia/comando_marinha > -Acesso em: 27/08/2018.

MELLO, J. L. P. Método de Borda propõe "democracia matemática". Folha de São Paulo, 11 de abril de 2002. Disponível em: https://www1.folha.uol.com.br/folha/educacao/ult305u8781.shtml >. Acesso em: 15 ago. 2006.

OLIVEIRA, T. R. C. Identificação e análise dos fatores críticos para implantação de negócios hoteleiros sustentáveis na APA Chapada do Araripe. Tese. 149p. (Doutorado em Engenharia Mecânica) - Universidade Estadual Paulista, UNESP, Bauru, SP, 2017.

PADILHA, L. D. Entrevista com Diretor Geral de Material da Marinha do Brasil - "Aviação Naval". 2018. Disponível em https://www.marinha.mil.br/content/dan-entrevista-o-diretorgeral-de-material-da-marinha-do-brasil-aviacao-naval. Acesso em: 27/08/2018.

PARETO, V. Course of political economy, 1896.

PRZEWORSKI, A.; STOKES, S. C.; MANIN, B. (Ed.). Democracy, accountability, and representation. Cambridge University Press, 1999.

RASKIN, S. F. Tomada de decisão e aprendizagem organizacional. In: Bate Byte 135, Publicação da CELEPAR - Companhia de Informática do Paraná, n. 135 - setembro/2006. Disponível em http://www.pr.gov.br/batebyte/edicoes/2006/bb135/tomada.shtml capturado em 06/07/2016.

ROY, B. Multicriteria methodology for decision aiding. Springer Science \& Business Media, 2013.

ROY, B.; BOUYSSOU, D. Aide multicritère à la décision: méthodes et cas. Paris: Economica, 1993. 
SAATY, T. L. Analytic heirarchy process. Wiley statsRef: Statistics reference online, 2014.

SIMON, H. A. Administrative behavior. Simon and Schuster, 2013.

STECYK, A. The analytic hierarchy process AHP for business intelligence system evaluation. European Journal of Service Management, v. 28, p. 439, 2018.

TRAMARICO, C. L. Avaliação multicritério da educação na gestão da cadeia de Suprimentos. Tese. 112p. (Doutorado em Engenharia Mecânica) - Universidade Estadual Paulista, UNESP, 2016.

TREINTA, F. T. et al. Metodologia de pesquisa bibliográfica com a utilização de método multicritério de apoio à decisão. Production, v. 24, n. 3, p. 508-520, 2014.

WALD, A. Statistical decision functions which minimize the maximum risk. Annals of Mathematics, p. 265-280, 1945.

WANG, J.J. et al. Review on multi-criteria decision analysis aid in sustainable energy decision-making. Renewable and sustainable energy reviews, v. 13, n. 9, p. 2263-2278, 2009.

YAGER, R. R. Pythagorean membership grades in multicriteria decision making. IEEE Transactions on Fuzzy Systems, v. 22, n. 4, p. 958-965, 2014.

YIN, R. K. Validity and generalization in future case study evaluations. Evaluation, v. 19, n. 3, p. 321-332, 2013. 